\title{
CULTURE OF PROTECTION AND RESCUE IN DENMARK
}

\section{Abstract}

The analysis of protection and rescue in Denmark, in terms of transnational dynamics and the compatibility or non-compliance of civil defense with the concepts of statehood, citizenship, or national goal - provides a comparison of the development of national civil defense in the West during the Cold War. Protection and rescue in Denmark is an example of the evolution of the civil defense system. The author tries to point out the functionality through the idea, construction, compliance, legal support but also the available critiques of the protection and rescue system. The reflections are on the timeliness of the conception, the legitimacy, and the presentation to the public of civil defense. Questions are asked about the success of the training methods for the professional staff and volunteers as well as the teaching to the general public; for the reproduction and materialization of political and cultural narratives of prosperity and war; for post-war urban planning; and for shelters as material and psychological support. The available data indicate that the continuous development of civil defense in Denmark in the Cold War and civil protection in the decades after it results in a system that is an example of the conceptual, structural, and functional setup of a modern and effective protection and rescue system.

Keywords: PROTECTION AND RESCUE, CIVIL DEFENSE, EMERGENCY, PREPAREDNESS, MANAGEMENT.

\section{Introduction}

The structure and functionality of the modern protection and rescue system in Denmark have their roots in the civil defense system that began to develop after the end of World War II. The Danish Civil Defense Project: A Culture of Fear and Cold War Survival provides the first comprehensive civil defense study in Denmark ${ }^{1}$. The development of the Danish civil defense is presented in two parts that focus separately on two periods, namely the early period 1945-

\footnotetext{
${ }^{1}$ The project complements the history of Denmark during the Cold War and contributes to a new theoretical framework that emphasizes the political, cultural and ideological dimensions of civil defense as well as facilitated international comparison in the field of protection and rescue.
} 
1964 and the later period 1964-1989, which examine the functionality of this system.

Founded in 1949, Danish civil defense gradually adapted to the threats of nuclear war during the 1950s. Despite the feelings and the transfer of responsibility for security away from the state and closer to the citizens (as a form of self-protection and self-rescue), in this period the need for a new and broader approach was emphasized. This is where the norms of gender and responsible citizenship promoted by the state and civil defense organizations, including the women's branch of the Civil Defense Association, come into play. The registered weaknesses are the transnational cycle of often incomplete efforts to educate the confused and often unconvinced public about the effects of the nuclear explosion and its consequences.

The research of the second period through three points is a general contribution to the international agenda for research of civil defense. First, it analyzes the Danish structure of civil defense until the end of the Cold War. Since the 1960s, Danish nuclear civil defense has increasingly been embedded in the architecture and ideology of the extended welfare state. ${ }^{2}$ Second, in terms of urban planning, it can be said that civil defense has always been an aspect of urban construction, but this was more urgent in the Cold War, as policymakers considered cities with high population concentrations to be particularly vulnerable. The national civil defense policy translates into urban civil defense, which is particularly evident with the transnational similarities and differences between nuclear and non-nuclear European countries. Third, the role of shelters as material construction and as a metaphor in tracing the post-war development of shelters and the role of materiality in creating cultural significance.

On this basis, in the past few decades, the continuous development of the protection and rescue system in Denmark has taken place, which is now an example of the conceptual, structural, and functional setup of a modern civil defense system. Today, the planning, organization, and implementation of protection and rescue in Denmark is the responsibility of the Emergency Management Agency. The Danish Emergency Management Agency (DEMA) was previously under the responsibility of the Ministry of the Interior, but since 1 February 2004, it has been under the Ministry of Defense (Retsinformation, 2009). ${ }^{3}$ The costs for protection and rescue that are directly related to the activities of the Danish Emergency Management Agency are around 63.3 million euros, which is $0.3 \%$ of GDP.

${ }^{2}$ The schools were built with extra wide doors and running water in the classrooms so that they could easily be transformed into emergency hospitals; public buildings, such as libraries and town halls, were equipped with shelters for the fall-out consequences; public parks were secretly designated areas for emergency cemeteries.

${ }^{3}$ Although, since then, DEMA is no longer called Civil Defense (Civilforsvaret), the general public still refers to it as Civil Defense, and many do not even know what DEMA is. 


\section{Structure of the protection and rescue system in Denmark}

The structure of the protection and rescue system is a reflection of the overall administrative structure. Danish citizens are protected by "3-level protection preparedness", and protection is provided by a combined government and municipal emergency system. Thus, Danish protection and rescue are structured on three levels: central, regional, and municipal.

\section{Central level}

At the central national level, the individual ministries are responsible, within their respective administrative spheres, for planning and taking the necessary measures for civil preparedness. The central government is responsible for:

- Planning and undertaking necessary measures for civil preparedness at the ministerial level;

- Coordination of civil preparedness planning, implementation of all related measures, and undertaking and implementation of tasks that were not performed by other bodies of the administration (implemented by the Ministry of Defense);

- Managing current crises and informing the public about the implemented measures and for that purpose a centralized website is created that contains all the information related to the crisis.

The government body directly responsible for protection and rescue is the Danish Emergency Management Agency, which is under the authority of the Ministry of Defense. As part of national planning, the Agency also coordinates the work of ministries in the context of NATO civil protection planning (European Commission, 2017).

\subsection{Regional level}

The national regional rescue preparedness consists of 5 regional centers. Regional centers provide support for municipal rescue preparedness whenever such assistance is needed, depending on the nature or extent of the accident or disaster. Emergency and disaster-related tasks are coordinated by regional coordination boards, which include representatives from the police, the local district, the Danish Emergency Management Administration, the Home Guard, and other relevant agencies depending on the nature of the crisis. The rescue preparedness system also provides a national reserve for emergency preparedness in times of crisis. So, the most important task of the regional rescue readiness system is the training of conscripts. 


\subsection{Local level}

According to the Law on Preparedness, municipalities must prepare an emergency plan for all tasks for which municipalities are responsible in times of peace, times of crisis, or war. The municipal rescue preparedness system must be able to provide appropriate response services. In addition, it should be prepared to receive, care for and feed evacuees and other distressed persons, including victims of floods and other natural disasters. The municipal rescue service is managed by the Municipal Commission for Contingency Planning, which according to the law is always headed by the mayor. The Commission is responsible for integrated civil protection planning, including risk assessment plans and operational response units.

\subsection{Interdepartmental competencies}

In order to strengthen coordination between the defense, the police, and other civilian authorities in the event of a major crisis in Denmark, a National Operations Headquarters (NOST) ${ }^{4}$ is being set up. Inter-agency coordination and high-level command and control are provided by the National Crisis Management Steering Group and NOST. The main task of the National Operations Headquarters is to play a coordinating role in the event of major incidents, accidents, and security threats, including terrorist acts in Denmark that cannot be solved by each regional police department, as well as tasks involving complex simultaneous events in different regions/parts of the country, which may require coordination at the national level (European Commission, 2017). ${ }^{5}$

\subsection{Other participants}

A) Private sector. A large Danish private fire and rescue company (Falck Redningskorps Ltd.) operates on a contractual basis within the municipalities. This company and other private companies at the regional level provide outpatient services.

B) Volunteers. The Danish Civil Protection League is a non-profit organization with 5,000 members. It is composed predominantly of volunteers in local rescue teams working for the safety of the civilian population and aims to be a

${ }^{4}$ The National Operations Headquarters includes the Chief of the Danish National Police, DEMA, the Danish Health Authority, the Defense Command, the Defense Intelligence Service (DDIS) and the Security Intelligence Service (PET), the Ministry of Foreign Affairs, and the Transport, Construction and Housing Authority. Other authorities may participate ad hoc.

${ }^{5}$ The main task of NOST is to create and maintain a quick overview of a particular situation and to provide an appropriate basis for decision-making to the responsible authorities and to provide a basis for the necessary coordination and prioritization of both problem solving and resources with the intention of submitting to relevant decision makers. 
unifying basis for volunteers engaged in municipal or national rescue preparedness. The League also aims to increase knowledge about preparedness and prevention among the population and through education of the population to increase its levels of self-protection and mass. ${ }^{6}$

C) NGOs. Among all of them, the Danish Red Cross is the most prominent with its participation.

\subsection{Environmental safety}

The Danish Marine Protection Act emphasizes the legal framework for controlling oil and chemical pollution offshore, on the shallow waters, and on the coast. According to the law, the Ministry of Environment, in cooperation with the military defense, local fire, and rescue services, and other authorities, was responsible for marine pollution control activities. However, since 2000 these tasks have been transferred to the Ministry of Defense, so the responsibilities related to marine pollution are given to the Defense Command and currently the Maritime Operations Command implements the response at sea and in shallow waters near the coast. Municipalities are responsible for the response on the coasts and ports.

\section{Civil defense}

\subsection{Danish Emergency Management Agency}

Today, the protection and rescue system in Denmark is significantly different from that of the Cold War. Protection and rescue are managed by the Danish Emergency Management Agency (DEMA), which is a government agency under the Ministry of Defense located in the Emergency Management and Home Guard department (Forsvarsministeriet, 2021). DEMA is in charge of:

- Coordination of responsibilities in the name of the Ministry of Defense;

- Management of emergency response centers;

- Supervision of national and local rescue preparedness;

- Advisory role on preparedness issues;

- Direct responsibility for fire protection;

\footnotetext{
${ }^{6}$ The Danish Civil Protection League is involved in the training and education of volunteers regarding the following measures: food supply and temporary accommodation, fire service, rescue, use of rescue dogs, communication and search and rescue teams. Additionally, the League offers first aid courses to all members as well as management courses for selected members. Furthermore, the League is involved in training the population for first aid, including the ability to put out small fires and deal with emergencies before they escalate into major accidents. Moreover, the League also offers training in the use of defibrillators and mediates between the supplier and the companies that need a defibrillator.
} 
- General development of emergency preparedness and response; and

- Chemical and nuclear responsibility (European Committee of Regions, 2020).

DEMA is organized in four essential areas, each covering part of the Danish emergency response: Operational response; Center for Education and Human Resources Development; Emergency planning, which includes overseeing the preparedness planning of other government, regional or municipal agencies and private companies; and Prevention, which includes the inspection, counseling, supervision, and development of national rules and regulations related to the technical and behavioral aspects of fire and explosion prevention (European Commission, 2017).

Its main task is to lead the operational segment consisting of six emergency management centers as well as an administrative and legal department that oversees national and local preparedness and serves as the government's advisory body on civil preparedness issues. In addition to the operational segment, i.e., The Emergency Operations Division also operates within DEMA: Nuclear Division, Chemical Division, and Civil Preparedness Division.

With the Danish Preparedness Act (Retsinformation, 2009), which entered into force on 1 January 1992, the former World War II Civil Defense Corps was transformed into a peacetime "Emergency Management Agency", which could primarily operate in peace. Specifically, the Danish Emergency Management Agency was created by the two agencies previously responsible for these services, namely the Civil Defense Agency and the Government Fire Inspection Agency. The Civil Defense was established on March 1, 1938, as the State Civil Defense (Statens civile luftværn) and was under the responsibility of the Ministry of the Interior. ${ }^{7}$ It was given the name Civil Defense by the first Civil Defense Law of April 1, 1949. With the help of a number of political agreements widely supported by the parties in the Danish Parliament, the rescue readiness, which was initially in the form of civil defense and protection, was constantly evolving and adapting to the changing demands of society and security policy changes into more non-military rescue form. Civil defense together with military defense, economic defense, and psychological defense constituted the unity of the defense system which was in accordance with at that time applied concept (policy) of total defense.

Currently, DEMA is able to deploy its facilities abroad at the request of another country or international organization. International interventions are regulated by political agreements. Denmark participates in the EU Emergency and Crisis Coordination Agreements (CCAs), with the Ministry of Foreign Affairs being the point of contact in relation to the CCA. Military interventions

${ }^{7}$ The Civil Defense Directorate and the Medical Sanitary Service Directorate were directly subordinated to the Ministry of Interior. Also, the Civil Defense Council acted within the Ministry, consisting of representatives from various departments and institutions directly responsible for the preparation and direction of the development of civil defense. The municipal fire services and the Government Fire Inspection Agency were under the Ministry of Justice. 
are regulated by the Law on Defense (Law 122 of February 2001), while civilian interventions are regulated by the Law on Civil Preparedness (LBK No. 137 of 2004 with amendments) (European Commission, 2017). DEMA is widely engaged in cross-border, European, and international cooperation in order to strengthen disaster management in Denmark, Europe, and beyond. This includes expanded cooperation with international organizations such as the EU, the UN, NATO, the Nordic countries, the Baltic Sea countries, and bilateral cooperation with Germany. ${ }^{8}$

The decision to provide assistance abroad is made in consultation with the Danish Ministry of Foreign Affairs. In this way, DEMA can provide support in cases of natural disasters and accidents, technological events, crises, and civil wars. DEMA is able to respond quickly to emergencies and leave its home base within a few hours on smaller missions and has the ability to operate a mobile hospital within 24 hours of being deployed to the scene of an accident (Beredskabsstyrelsen, 2010). The capacity for such action nowadays is inherited from the activities of the former Administration of Medical Sanitary Service in whose domain were the competencies for the preparation of hospitals and staff to provide medical assistance to injured and sick civilians. In conditions of war, it was planned to transform the Administration into the so-called Danish hospital emergency care that will provide medical assistance to the civilian population. The base of the Danish Mobile Emergency Hospital (DEMH) is the DEMA Regional Volunteer Center (in Hadehusene) with a capacity of 300 volunteers, with its Mobile Trauma Care Unit (MTCU) (Danish Emergency Management Agency, 2011). ${ }^{9}$

\subsubsection{Emergency operations}

Emergency operations in Denmark are carried out through the municipal and regional activities and services of the Danish Emergency Management Agency. There is no system of subordination between regions and municipalities, as they have different tasks and responsibilities. Denmark is divided into 98 municipalities organized into 5 regions (European Commission, 2017). Mu-

\footnotetext{
${ }^{8}$ Some notable operations since the 1990s are: Delivery of aid to Bosnia in 1992 (where a convoy was attacked and a Danish civil defense non-commissioned officer was killed); Search and rescue after the 1992 earthquake in Turkey; Mobile Hospital in Afghanistan; Aceh Mobile Hospital after the 2004 Indian Ocean earthquake and tsunami; Evacuation of Danish civilians from Lebanon during the 2006 conflict; The 2010 earthquake in Pakistan; Disaster after the 2011 earthquake in Japan and the Fukushima nuclear incident. ${ }^{9} \mathrm{DEMH}$ is a highly specialized hospital for orthopedic surgery. The hospital is deployed to disaster scenes abroad, mainly earthquakes and earthquake-related disasters, but has also been deployed in complex emergencies. MTCU is part of the capacity of DEMA for urban search and rescue (USAR), intended for initial trauma care and stabilization of the transport of injured members of the urban search and rescue team and for stabilization of the victims rescued by the USAR team. Furthermore, MTCU is part of the Danish Emergency Hospital, which can be deployed as a mobile team, capable of returning patients from remote areas.
} 
nicipal authorities are responsible for supplying and preparing for emergencies and creating contingency plans for all tasks for which municipalities are responsible. Regional authorities are responsible for managing hospitals and regional national rescue preparedness centers.

A) Municipal fire departments. The primary firefighting work in Denmark is done by the municipal fire services and all municipalities are required by law to have a fire service. Prior to 1992, the municipal fire service was controlled by the Government Fire Inspection Agency, but with the amendment of the law in 1992, the responsibility was given to the DEMA Civil Preparedness Department. The municipalities are not obliged to completely put out the fire themselves, so most of the activities of the fire service are done by a private company.

B) Regional support centers. The Emergency Management Agency has a staff of about 600 people. About 170 of them are employed at the headquarters of the agency in Birkerod. The rest are employed in the agency's six centers and two schools. It is possible to perform recruitment services from Danish conscripts in the operational part of DEMA, where the agency has about 450 recruits every 9 months ${ }^{10}$. The recruits receive full education for firefighters and are trained in the following areas: Fire protection; Rescue and Urban Search and Rescue (USAR); Advanced first aid, patient assessment, and treatment (at the level of medical first aid technician); Communications ${ }^{11}$; Use of heavy vehicles; and Hazard materials.

Six regional emergency management centers are deployed across the country so that almost any part of the country can be reached within one hour of receiving the alarm. Each of the centers has recruits accommodated in the barracks who, in addition to general training, also undergo specialist training that is different in each of the centers, such as: specialization in resuscitation devices, specialization in international operations, specialization in protective equipment, specialization in heavy vehicles and volunteers (Danish Emergency Management Agency, 2011). The primary function of the above centers is to assist municipal fire departments in the event of a major fire, to assist the police, and to take care of Danish preparedness for radioactive fallouts, hazardous material readiness, urban rescue readiness, and other relevant tasks. The Hedehusene Center is fully a volunteer center, with the exception of the Chief Officer and some teachers who offer courses to private rescue companies. All other centers are staffed by recruits who are controlled by one officer and several non-commissioned officers.

\footnotetext{
${ }^{10}$ Unlike the military where the normal length of service is 4 months and there are no operational tasks, the conscription service in DEMA is 9 months in length. Recruits also become part of the national emergency response after 1 month of service and often participate in fire and rescue operations.

${ }^{11}$ A Command and Communications Module is often used to support large police operations.
} 


\subsubsection{Departments and emergency management schools}

A) Nuclear department. Responsibilities of this department include: inspections of the shutdown of the only nuclear facility in Denmark near Riso; Denmark nuclear readiness; international cooperation on nuclear safety and nuclear readiness within the Nordic countries, EUROATOM, International Atomic Energy Agency (IAEA) and OSCE; and Nuclear Assistance Programs for Eastern European Countries.

B) Chemical department. Its responsibilities include: analytical chemical investigations of unknown substances, including chemical warfare agents and explosives; testing of hazardous materials and hazardous materials (including hazardous materials including toxic industrial chemicals, explosives, chemical warfare substances, and other hazardous substances; advisory services, including the National Center for Chemical Response, Education and Science (Beredskabsstyrelsen, 2010). The Department for Chemical Contingency at the Danish Emergency Management Agency is made up of chemists who can work around the clock to provide telephone advice, chemical analysis, and assistance in accidents and crime scenes around the clock. More specifically, the department can assist in situations of: releasing hazardous substances; fire containing dangerous substances or emission of dangerous fumes; traffic accidents with dangerous substances; sampling at the scene (eg by finding chemically illegal laboratories and after explosions); chemical analysis, in particular the identification of unknown substances (eg by contamination of drinking water or in case of poisoning by ingestion of various liquids or solids or by detection of unknown objects); preliminary identification of chemical substances at the scene of the accident using mobile equipment; final identification in the laboratory of chemical substances using advanced analysis equipment; treatment of chemically contaminated persons; cleaning and decontamination of staff and emergency equipment; estimation of safety distances and spread of substances based on current weather data from the Danish Meteorological Institute; chemical terrorism (Beredskabsstyrelsen, 2010).

Samples taken across the country in the event of an acute accident involving dangerous substances are usually submitted to the Danish Chemical Division of the Danish Emergency Management Agency for chemical identification of the contents. ${ }^{12}$

The department also functions as the Danish Center for Chemical Emergencies (ICE), which mediates contact between experts from the Danish chemical industry in an emergency. ICE stands for Chemical Transport Emergency Intervention. The ICE Centers are part of the European Emergency Response

\footnotetext{
${ }^{12}$ True sampling is part of the preparation that builds and functions in everyday life. Sampling in the hazardous area is performed by a chemical team in agreement with the rescue service from the municipal or state rescue service, in accordance with the chemical contingency guidelines. In addition, sampling is performed either by the emergency services, the Center for Forensic Medicine, the Ammunition Clearance Service of the Armed Forces or the Chemical Emergency Services, by mutual agreement.
} 
Network under the European Chemical Industry Council. In addition, the national center department can provide advice between European rescue services and chemical companies in the event of accidents with Danish products abroad or foreign products in Denmark (Beredskabsstyrelsen, 2010).

C) Department of Civil Preparedness. Danish preparedness law stipulates that every ministry, agency, or other body in the Danish government is required to carry out relevant planning within their sector to deal with a serious negative impact on the critical functions of society. The department helps facilitate planning in different sectors and coordination between different sectors. This includes responsibility for national emergency planning, publishing guidance materials, courses, and other activities to strengthen cooperation between the various actors in the Danish civil preparedness system.

D) Schools for emergency management are DEMA College of Personnel (in Snekersten) and DEMA Technical College (in Tinglev). These training centers provide professional educational consulting services to schools, centers, and the municipal civil protection preparedness system, including training regulations and staff preparedness plans; administration training courses; management and development of national and internal training courses and exercises; staff recruitment, staff administration, and staff policy; cooperation with national and international universities and civil protection training centers.

\section{National Emergency Management}

The National Emergency Management System is intended to provide government coordination of incident response in Denmark and abroad. It consists of:

- Government Committee on Security, which includes the Prime Minister as chair and the Ministers of Foreign Affairs, Justice and Defense;

- Security Committee of High Representatives, which includes the permanent secretaries of the above-mentioned 4 ministers and the heads of the Defense Intelligence Service and the Security Intelligence Service;

- National Operations Headquarters (NOST);

- International Operations Headquarters (IOS); ${ }^{13}$

- 12 local operational headquarters with permanent members from: police districts, DEMA, Territorial Defense (Home Guard), regions,

${ }^{13}$ The IOS includes the Ministry of Foreign Affairs as the chair, the Office of the Prime Minister, the Ministry of Justice, the Ministry of Defense, the Ministry of Health, the National Police, DEMA, the Danish Health Administration and the Defense Command. Other authorities, representatives of the transport and insurance industry can participate ad hoc. 
and municipalities. Ad hoc participants often include public transport and utility providers;

- Local incident command, which is formed at the scene of the incident by incidental commanders of police, fire, and rescue, and health preparedness (National Civil Protection Authority, 2019).

\subsection{Prevention}

Within their areas, individual ministries must plan to maintain and extend the functions of society in the event of large-scale accidents and catastrophes, including the creation of contingency plans. Each municipal and regional council must also prepare a regional/municipal emergency management plan. 24 municipal fire and rescue companies (owned by 98 municipalities) must separately update a plan based on local risks and conditions. The Ministry of Defense, through DEMA, coordinates the plans, advises the authorities, and provides guidance for the preparation of the plans of the central government authorities, regions, municipalities, and municipal fire and rescue companies. Plans must be reviewed at least once every 4 years and submitted to DEMA for review and comment.

Risk assessment. The Danish National Risk Assessment is conducted by DEMA in close consultation with other governing bodies and organizations. The results are summarized in a paper entitled National Risk Profile (NRP).

Risk management planning. In addition to the Danish Emergency Management Law, risk management planning is addressed in several other acts: National Emergency Plan, Comprehensive Preparedness Guidelines, National Accident and Disaster Prevention Strategy, and other sector-specific legislation such as e.g. Readiness for health, transport, and energy sector. The emphasis is on the general plans for all accidents, i.e., the focus is on the essential tasks of crisis management regardless of the scenario. Emergency plans for specific risks are made by and for all members of the national crisis management system.

Risk communication and awareness-raising. Denmark operates with sectoral responsibility that extends to risk communication and awareness. This means that the sector responsible for the area in which there is public risk is also responsible for communication-related to that risk. DEMA conducts a two-year public awareness survey on the threats profiled in the National Risk Profile.

At the national level, the warning system, which consists of a system of sirens across the country and a direct connection to national broadcasters, which in serious emergencies are obliged to post and broadcast warning messages - is tested once a year, both for the test and for to create public awareness. This system is supplemented with information from the SMS service for the hearing impaired, with warning applications, and with social media and web platforms of the administrative bodies (National Civil Protection Authority, 2019). 


\subsection{Emergency preparedness and response}

Training and exercises. DEMA and other organizations offer a wide range of training courses. Only DEMA conducts 32 courses for its own staff and other sectors, ranging from courses related to the functioning of commanders at the scene to crisis communication courses. There are also plenty of training opportunities through numerous exercises (procedure, dilemma, crisis management, etc.).

Early warning system. Early warning systems in Denmark are extremely time-related. These include a slippery slope warning from road measurements displayed on government websites and applications and are the basis for traffic radio information. DEMA also maintains a nuclear and radiological emergency warning system. The system consists of 11 automatic measuring stations located throughout the country. In the event of increased radiation from any of these 11 locations, DEMA receives an automatic alarm and can respond.

Emergency response. In Denmark, the basic principle for emergency management and response is sectoral responsibility. This means that the authorities or the organization with day-to-day responsibility for a particular area are also responsible for that area in case of an emergency. Municipal fire and rescue services are responsible for rapid response in an emergency, while DEMA assists in larger or more complex incidents that require special equipment or personnel (National Civil Protection Authority, 2019).

\section{Conclusion}

In the first period of the Cold War, civil defense in Denmark was an authoritative debate on the transformation of state-citizen relations, the promotion of social norms, and the discipline of citizens through education and visual effects. In the second period, the Danish civil defense becomes nuclear civil defense followed by changes in the welfare state, urban planning, and materiality in the culture of protection and rescue. Nowadays, Danish citizens are protected by "3-level protection preparedness", and protection is provided by a combined government and municipal emergency system. The governing body is the Danish Emergency Management Agency, which is organized into four essential areas, each covering part of the Danish Emergency Response: Operational Response; Center for Education and Human Resources Development; Emergency planning; and Prevention. The system encompasses the private sector, volunteers, and NGOs. The National Crisis Management System is intended to provide government coordination of incident response in Denmark and abroad. 


\section{References:}

Beredskabsstyrelsen. (2010). ‘Danish Emergency Mobile Hospital'.https:// web.archive.org/web/20100821201354/http://www.brs.dk/brsfh/ Dokumenter/DEMH.pdf

Beredskabsstyrelsen. (2010). 'Information on hazardous materials'.https://web. archive.org/web/20101015080334/http://www.kemikalieberedskab.dk/ english.shtml

Danish Emergency Management Agency. (2011). ‘Volunteer Centre'.https:// web.archive.org/web/20110719014017/http://www.brs.dk/brsfh/ internationalt/english_version.htm

European Commission. (2017). ‘Humanitarian Aid \& Civil Protection. Denmark - Disaster management Structure'. https://ec.europa.eu/echo/files/civil_ protection/vademecum/dk/2-dk-1.html\#over

European Committee of Regions. (2020). 'Division of Powers. Denmark Civil protection'. https://portal.cor.europa.eu/divisionpowers/Pages/ Denmark-Civil-protection.aspx

Forsvarsministeriet (FMN). (2021). ‘Departmentents organisation'.https://fmn. $\mathrm{dk} / \mathrm{da} /$ ministeriet/forsvarsministeriet/departementets-organisation/

National Civil Protection Authority.(2019). 'European Civil Protection and Humanitarian Aid Operations'. Facts \& Figures. Denmark. https:// ec.europa.eu/echo/what/civil-protection/disaster-management/ denmark_en

Retsinformation. (2009). 'Beredskabsloven in Danish'. https://www. retsinformation.dk/eli/lta/2009/660 
